\title{
Reactive nitrogen/oxygen species production by nitro/nitrosyl supramolecular ruthenium porphyrin complexes
}

\author{
M.I.F. Barbosa ${ }^{a, i, 1}$, G.G. Parra ${ }^{\mathrm{b}, 1}$, R.S. Correa ${ }^{\mathrm{c}}$, R.N. Sampaio ${ }^{\mathrm{d}}$, L.N. Magno ${ }^{\mathrm{e}}$, R.C. Silva ${ }^{\mathrm{f}}$, \\ A.C. Doriguetto ${ }^{a}$, J. Ellena ${ }^{g}$, N.M. Barbosa Neto ${ }^{\text {h }}$, A.A. Batista ${ }^{i}$, P.J. Gonçalves ${ }^{\mathrm{e}, \mathrm{f}, *}$ \\ a Instituto de Química, Universidade Federal de Alfenas, 37130-000, Alfenas, MG, Brazil \\ ${ }^{\mathrm{b}}$ Departamento de Física, FFCLRP, Universidade de São Paulo, 14040-901, Ribeirão Preto, SP, Brazil \\ ' Departamento de Química, ICEB, Universidade Federal de Ouro Preto, 35400-000, Ouro Preto-MG, Brazil \\ d Department of Chemistry, University of North Carolina, Chapel Hill, NC, USA \\ e Instituto de Física, Universidade Federal de Goiás, 74001-970 Goiânia, GO, Brazil \\ f Instituto de Química, Universidade Federal de Goiás, 74001-970 Goiânia, GO, Brazil \\ g Instituto de Física de São Carlos, Universidade de São Paulo, CP 369, 13560-970, São Carlos, SP, Brazil \\ ${ }^{\mathrm{h}}$ Instituto de Ciências Exatas e Naturais, Universidade Federal do Pará, 66075-110, Belém, PA, Brazil

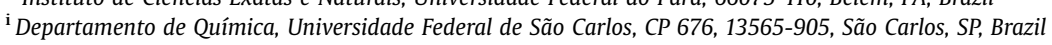

\section{A R T I C L E I N F O}

\section{Article history:}

Received 20 October 2016

Received in revised form 29 January 2017

Accepted 30 January 2017

Available online 11 February 2017

\section{Keywords:}

NO

Photorelease

ROS

Triplet states

Photophysical properties

PDT

\begin{abstract}
A B S T R A C T
This manuscript reports on new nitro/nitrosyl Ru-based complexes, which were synthesized with the purpose of using them as precursors to obtain supramolecular ruthenium porphyrin species ( $\{\mathrm{TPyP}[\mathrm{Ru}$ $\left.\left.\left.\left(\mathrm{NO}_{2}\right)\left(5,5^{\prime} \text {-Mebipy }\right)_{2}\right]_{4}\right\}\left(\mathrm{PF}_{6}\right)_{4}\right)$ and $\left(\left\{\mathrm{TPyP}\left[\mathrm{Ru}(\mathrm{NO})\left(5,5^{\prime}-\mathrm{Mebipy}\right)_{2}\right]_{4}\right\}\left(\mathrm{PF}_{6}\right)_{12}\right)$. The photochemical and photophysical properties of these porphyrin species were investigated. Results show that the complex containing nitrite is able to produce NO by homolytic O-NO cleavage $\left(\Phi_{N O}^{P P h}=0.05\right)$ while the $\{\mathrm{TPyP}[\mathrm{Ru}$ $\left.\left.(\mathrm{NO})\left(5,5^{\prime}-\mathrm{Mebipy}\right)_{2}\right]_{4}\right\}\left(\mathrm{PF}_{6}\right)_{12}$ does it by direct labilization $\left(\Phi_{\mathrm{NO}}^{P P h}=0.53\right)$ of the $\mathrm{Ru}-\mathrm{NO}$ bond. Furthermore, a triplet quantum yield of 0.09 and 0.27 was observed for complexes containing nitrite and nitric oxide, respectively. The reactive oxygen species quantum yield for the complex $\{\mathrm{TPyP}[\mathrm{Ru}(\mathrm{NO})$ $\left.\left.\left(5,5^{\prime} \text {-Mebipy }\right)_{2}\right]_{4}\right\}\left(\mathrm{PF}_{6}\right)_{12}(0.78)$ is consistent with the sum of quantum yields NO release $(0.53)$ and triplet state (0.27), which suggests that both processes participate in the formation of the reactive species. Our results show that combining these characteristics, NO production and triplet states, on the same platform could induce a synergic effect, leading to a considerable improvement in the photodynamic action of these complexes.
\end{abstract}

(c) 2017 Elsevier B.V. All rights reserved.

\section{Introduction}

Photochemotherapy is a clinical treatment method, whereby cancer cells can be destroyed combining light and a photosensitizer drug (PS). Photodynamic Therapy (PDT) is one of the most known techniques that combine visible or near-infrared light, a PS and a suitable amount of molecular oxygen [1-3]. Nowadays, photodynamic action is accepted as one of the various methods

\footnotetext{
* Corresponding author at: Instituto de Física, Universidade Federal de Goiás, 74001-970, Goiânia, GO, Brazil.

E-mail address: pablo@ufg.br (P.J. Gonçalves).

1 These authors contributed equally to this manuscript.
}

available to treat different kinds of cancer and other clinical applications [4-9].

Currently, many studies are being carried out aiming to develop more efficient PS molecules [10-13], as well as to discover more efficient photodynamic mechanisms [13-16]. Among the various strategies reported in the literature, ruthenium complexes have received a great deal of attention as potential PDT agents [17-22].

Typically, photodynamic action can be described as two distinct mechanisms: Type I mechanism, which is based on the production of free radicals, such as ${ }^{\bullet} \mathrm{OH}, \mathrm{HO}_{2}{ }^{\bullet}, \mathrm{O}_{2}{ }^{\bullet}$ and type II mechanism, involving energy transfer to the molecular oxygen. Both processes can induce damage to membranes, DNA and other biomolecules, which can lead to cellular death by necrosis or apoptosis [23,24]. A third mechanism has been reported for ruthenium-NO complexes $[25,26]$, which involves the photorelease of the NO radical, which 
can also be important for hypoxic regions. Combining these mechanisms on the same platform, which could be able to induce a synergic effect resulting in a considerable improvement of photodynamic action, is strongly desirable.

Furthermore, nitric oxide (NO) has been described as an antitumor agent $[27,28]$, which, combined with reactive oxygen species, (ROS) produces a synergistic photodynamic action between ROS and reactive nitrogen species (RNOS) $[25,26,29,30]$. It was shown that using UV-vis irradiation on a NO-compound leads to tumor destruction [29]. Considering the role of NO in cancer therapy and the high triplet quantum yield of porphyrins and phthalocyanines, we decided, rationally, to design supramolecular ruthenium porphyrin complexes that could have these desirable properties. Considering this, nitrosyl ruthenium complexes were synthesized, which were able to photo-release NO and also produce triplet states $[25,26,29,30]$. Thus, in this work, the synthesis and characterization of two new supramolecular ruthenium porphyrin complexes, $\left\{\mathrm{TPyP}\left[\mathrm{Ru}(\mathrm{NO})\left(5,5^{\prime}-\mathrm{Mebipy}\right)_{2}\right]_{4}\right\}$ $\left(\mathrm{PF}_{6}\right)_{12}$ and $\left\{\mathrm{TPyP}\left[\mathrm{Ru}\left(\mathrm{NO}_{2}\right)\left(5,5^{\prime}-\mathrm{Mebipy}\right)_{2}\right]_{4}\right\}\left(\mathrm{PF}_{6}\right)_{4}$, are presented, and the purpose is to study their photodynamic properties.

\section{Materials and methods}

\subsection{Chemicals for the synthesis}

Solvents were purified using standard methods. All chemicals used were of reagent grade or comparable purity. $\mathrm{RuCl}_{3} \cdot 3 \mathrm{H}_{2} \mathrm{O}, 5,5^{\prime}-$ dimethyl-2,2'-bipyridine (5,5'-Mebipy), 5,10,15,20-Tetra(4-pyridyl)porphyrin (TPyP), sodium nitrite and hexafluorphosphoric acid were used as received from Aldrich.

\subsection{Synthesis}

cis- $\left[\mathrm{RuCl}_{2}\left(5,5^{\prime} \text {-Mebipy }\right)_{2}\right]$ (1), cis- $\left[\mathrm{Ru}\left(\mathrm{NO}_{2}\right)_{2}\left(5,5^{\prime} \text {-Mebipy }\right)_{2}\right]$ (2), and cis-[Ru(NO)(NO 2$\left.)\left(5,5^{\prime} \text {-Mebipy }\right)_{2}\right]\left(\mathrm{PF}_{6}\right)_{2}$ (3) were developed as precursors to coordinate the porphyrin by the peripheral pyridine rings, leading to the formation of $\operatorname{TPyP}\left\{\left[\mathrm{Ru}\left(\mathrm{NO}_{2}\right)\left(5,5^{\prime}\right.\right.\right.$-Mebipy) $]\}_{4}\left(\mathrm{PF}_{6}\right)_{4}$ (4) and $\operatorname{TPyP}\left\{\left[\mathrm{Ru}(\mathrm{NO})\left(5,5^{\prime} \text {-Mebipy }\right)\right]\right\}_{4}\left(\mathrm{PF}_{6}\right)_{12} \quad$ (5) species. Complexes (1-3) are analogues described in the literature for 2,2-bipiridine [31,32]. The synthetic route for these syntheses is illustrated in Scheme 1.

\section{$\left[\operatorname{RuCl}_{2}\left(5,5^{\prime} \text {-Mebipy }\right)_{2}\right] \cdot 2 \mathrm{H}_{2} \mathrm{O}$}

In a Schlenk flask with $10 \mathrm{~mL}$ of degassed dimethylformamide, $1.0 \mathrm{~g}$ ( $3.8 \mathrm{mmol})$ of $\mathrm{RuCl}_{3} \cdot 3 \mathrm{H}_{2} \mathrm{O}, 1.2 \mathrm{~g}$ (6.5 mmol) of 5,5'-Mebipy and $1.1 \mathrm{~g}(25.9 \mathrm{mmol})$ of lithium chloride were added, as described in the literature [31]. The reaction was stirred and heated for $8 \mathrm{~h}$ at $130^{\circ} \mathrm{C}$. At the end of the reaction time, it was cooled down and $50 \mathrm{~mL}$ of cold acetone were added. The flask was left in the fridge for $1 \mathrm{~h}$. The solution was filtered and the dark solid was washed in ice water and ether. Yield 91.4\%. Elemental analysis (\%) calc. for $\mathrm{C}_{24} \mathrm{H}_{28} \mathrm{Cl}_{2} \mathrm{~N}_{4} \mathrm{O}_{2} \mathrm{Ru}$ : C 50.60, H 4.90, N 9.72. Found: C 50.86, H 4.70 and $\mathrm{N}$ 10.07. Conductivity (dichloromethane): $1.44 \mathrm{ohm}^{-1} \mathrm{~cm}^{2}$ $\mathrm{mol}^{-1}, \mathrm{~T}=298 \mathrm{~K}$ (neutral electrolyte).

$$
\left[\mathrm{Ru}\left(\mathrm{NO}_{2}\right)_{2}\left(5,5^{\prime} \text {-Mebipy }\right)_{2}\right]
$$

In a Schlenk flask, $0.30 \mathrm{~g}(0.5 \mathrm{mmol})$ of $\mathrm{cis}$-[ $\left[\mathrm{RuCl}_{2}\left(5,5^{\prime} \text {-Mebipy }\right)_{2}\right.$ was suspended in $50 \mathrm{~mL}$ of water, boiled for $15 \mathrm{~min}$ and stirred. The deep red solution was cooled down to room temperature and filtered and $0.90 \mathrm{~g}(7.8 \mathrm{mmol})$ of sodium nitrite was added. The solution was then refluxed for $90 \mathrm{~min}$. The flask was cooled for $1 \mathrm{~h}$, then filtered and washed with water and ether $(3 \times 5 \mathrm{~mL})$ [32].

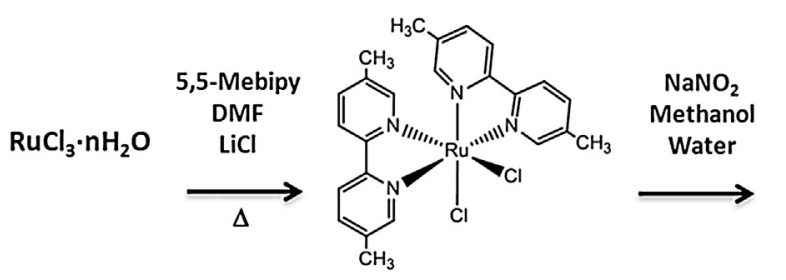

(1)<smiles></smiles>

(2)

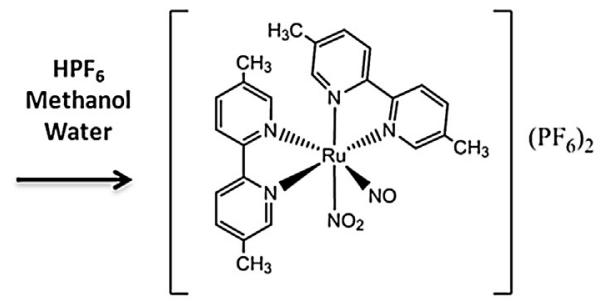

(3)

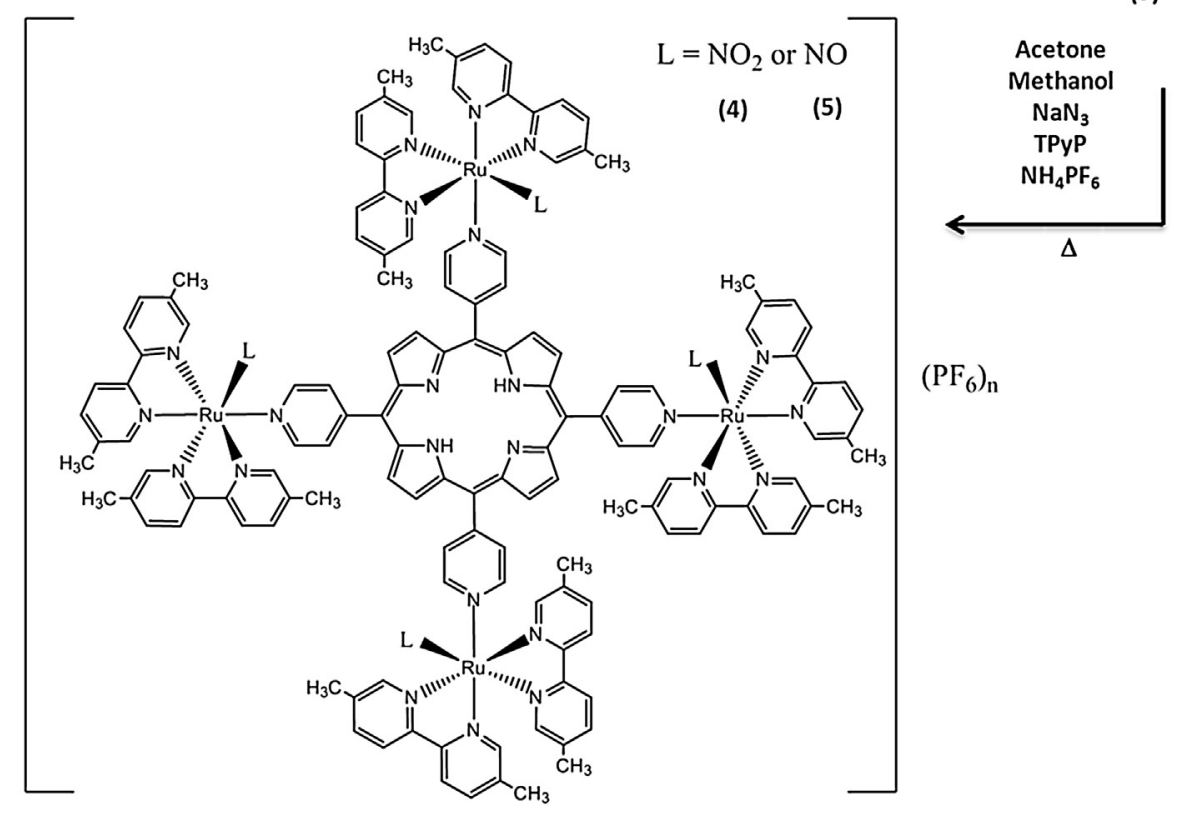

Scheme 1. Representation of the route for the synthesis of complexes (1)-(5). 
Yield 94.0\%. Elemental analysis (\%) calc. for $\mathrm{C}_{24} \mathrm{H}_{24} \mathrm{~N}_{6} \mathrm{O}_{4} \mathrm{Ru}$ : C 51.33, H 4.31, N 14.97. Found: C 50.95, H 4.49 and N 15.39. Conductivity (dichloromethane): $1.80 \mathrm{ohm}^{-1} \mathrm{~cm}^{2} \mathrm{~mol}^{-1}, \mathrm{~T}=298 \mathrm{~K}$ (neutral electrolyte).

$\left.\mathrm{Ru}(\mathrm{NO})\left(\mathrm{NO}_{2}\right)\left(5,5^{\prime}-\mathrm{Mebipy}\right)_{2}\right]\left(\mathrm{PF}_{6}\right)_{2}$

A sample of $0.20 \mathrm{~g}(0.4 \mathrm{mmol})$ of cis-[Ru( $\left.\left(\mathrm{NO}_{2}\right)_{2}\left(5,5^{\prime}-\mathrm{Mebipy}\right)_{2}\right]$ was suspended in $10 \mathrm{~mL}$ of degased methanol and was stirred. Then $2 \mathrm{~mL}$ of concentrated $\mathrm{HPF}_{6}$ were added dropwise. After $15 \mathrm{~min}$, the orange solid was converted into a yellow solid, which was filtered off and washed in methanol and ether $(3 \times 5 \mathrm{~mL})$ [32]. Yield 94.0\%. Elemental analysis (\%) calc. for $\mathrm{C}_{24} \mathrm{H}_{24} \mathrm{~F}_{12} \mathrm{~N}_{6} \mathrm{O}_{3} \mathrm{P}_{2} \mathrm{Ru}$ : C 34.50, H 2.90, N 10.06. Found: C 34.38, H 2.87 and N 9.95. Conductivity (methanol): $165.7 \mathrm{ohm}^{-1} \mathrm{~cm}^{2} \mathrm{~mol}^{-1}, \mathrm{~T}=298 \mathrm{~K}$ (electrolyte $2: 1)$.

$\left\{\mathrm{TPyP}\left[\mathrm{Ru}\left(\mathrm{NO}_{2}\right)\left(5,5^{\prime}-\mathrm{Mebipy}\right)_{2}\right]_{4}\right\}\left(\mathrm{PF}_{6}\right)_{4}$

In a Schlenk flask, $0.30 \mathrm{~g}(0.3 \mathrm{mmol})$ of cis-[Ru(NO)(NO $\left.\mathrm{NO}_{2}\right)\left(5,5^{\prime}-\right.$ Mebipy $\left.)_{2}\right]\left(\mathrm{PF}_{6}\right)_{2}$ were suspended in $20 \mathrm{~mL}$ of acetone and stirred vigorously. An equimolar amount of sodium azide $\left(\mathrm{NaN}_{3}\right)(0.023 \mathrm{~g}$, $0.36 \mathrm{mmol}$ ) was dissolved in $5.0 \mathrm{~mL}$ of methanol and was added slowly, dropwise to the above solution. After $10 \mathrm{~min}, 0.05 \mathrm{~g}$, $(0.08 \mathrm{mmol})$ of TPyP, previously dissolved in $20 \mathrm{~mL}$ of chloroform, was added and the flask was wrapped in aluminum foil and heated $\left(60^{\circ} \mathrm{C}\right)$. After $24 \mathrm{~h}$ of reaction, its volume was reduced to approximately $1 \mathrm{~mL}$ and $\mathrm{NH}_{4} \mathrm{PF}_{6}(0.5 \mathrm{~g}, 3.0 \mathrm{mmol})$, solubilized in $1 \mathrm{~mL}$ of methanol, was added. Then ethyl ether was added to precipitate a brown solid. The flask remained in the refrigerator for about $1 \mathrm{~h}$. The formed solid was filtered off and washed several times in water to remove remaining $\mathrm{NH}_{4} \mathrm{PF}_{6}$ and with ether $(3 \times 5 \mathrm{~mL})$. Yield: $90.0 \%$. Elemental analysis (\%) calc. for $\mathrm{C}_{136} \mathrm{H}_{122} \mathrm{~F}_{24} \mathrm{~N}_{28} \mathrm{O}_{8} \mathrm{P}_{4} \mathrm{Ru}_{4}$ : C 49.99, H 3.98 and $\mathrm{N}$ 12.00. Found: $\mathrm{C}$ 49.08, H 3.65, N 12.12 .

$\left\{\mathrm{TPyP}\left[\mathrm{Ru}(\mathrm{NO})\left(5,5^{\prime}-\mathrm{Mebipy}\right)_{2}\right]_{4}\right\}\left(\mathrm{PF}_{6}\right)_{12}$

A mass of $\left\{\mathrm{TPyP}\left[\mathrm{Ru}\left(\mathrm{NO}_{2}\right)\left(5,5^{\prime}-\mathrm{Mebipy}\right)_{2}\right]_{4}\right\}\left(\mathrm{PF}_{6}\right)_{4} \quad(0.2 \mathrm{~g}$, $0.06 \mathrm{mmol}$ ) was dissolved in $20 \mathrm{~mL}$ of acetonitrile. $1 \mathrm{~mL}$ of $\mathrm{HPF}_{6}$, diluted in $5 \mathrm{~mL}$ of methanol was added to this solution and stirred for $2 \mathrm{~h}$. After that, the volume of the solution was reduced to about $2 \mathrm{~mL}$ and $20 \mathrm{~mL}$ of cold water was added, leading to a formation of a light brown precipitate that was collected by filtration and washed several times in cold water and ethyl ether. Yield: $90.0 \%$. Elemental analysis (\%) calc. for $\mathrm{C}_{136} \mathrm{H}_{122} \mathrm{~F}_{72} \mathrm{~N}_{28} \mathrm{O}_{4} \mathrm{P}_{12} \mathrm{Ru}_{4}$ : C 37.10, $\mathrm{H} 2.82$ and $\mathrm{N}$ 9.00. Found: C 36.87, H 2.67, N 9.12.

\subsection{Instrumentation}

Elemental analyses were performed in a Fisons EA 1108 model (Thermo Scientific, Waltham, Massachusetts). The FTIR spectra of the complexes were recorded using CsI pellets in the 4000$200 \mathrm{~cm}^{-1}$ region in a FT MB-102 instrument (Bomen-Michelson). The UV-vis spectra of the complex was recorded in $\mathrm{CH}_{2} \mathrm{Cl}_{2}$ for complex (1), in acetonitrile for complexes (2)-(3) and DMSO for complexes (4) and (5) in a Hewlett Packard diode array - 8452A. Cyclic voltammetry (CV) measurements of the complexes were performed in an electrochemical analyzer BAS model $100 \mathrm{~B}$ (Bioanalytical Systems, West Lafayette, Indiana). These experiments were carried out at room temperature in previously degassed $\mathrm{CH}_{2} \mathrm{Cl}_{2}$ for complex (1), acetonitrile for complexes (2)(3) and DMF for complex (4)-(5), containing $0.1 \mathrm{~mol} \mathrm{~L}^{-1}$ $\mathrm{Bu}_{4} \mathrm{~N}^{+} \mathrm{ClO}_{4}^{-}$(PTBA) (FlukaPurum, St. Louis, MO) as a supporting electrolyte. A one-compartment cell was used with both working and auxiliary electrodes, which were stationary Pt foils, while the reference electrode was $\mathrm{Ag} / \mathrm{AgCl}, 0.1 \mathrm{~mol} \mathrm{~L}^{-1}$ PTBA. Under such conditions, the ferrocene is oxidized at $0.43 \mathrm{~V}\left(\mathrm{Fc}^{+} / \mathrm{Fc}\right)$. All the NMR spectra were recorded at $298 \mathrm{~K}$ and measured using a 9.4 T Bruker Avance III spectrometer. The molar conductivity measurements $(\Lambda \mathrm{m})$ were taken in acetone, dichloromethane and methanol at $298 \mathrm{~K}$ using concentrations of $1.0 \times 10^{-3} \mathrm{M}$ of the complexes.

\subsection{X-ray crystallography}

Orange crystals of cis-[Ru( $\left.\left.\mathrm{NO}_{2}\right)_{2}\left(5,5^{\prime}-\mathrm{Mebipy}\right)_{2}\right]$ (2) and cis-[Ru $\left.(\mathrm{NO})\left(\mathrm{NO}_{2}\right)\left(5,5^{\prime} \text {-Mebipy }\right)_{2}\right] \quad\left(\mathrm{PF}_{6}\right)_{2}$ (3) were obtained by slow evaporation of a methanol/hexane solution $(2: 1)$ at $298 \mathrm{~K}$. The data collection was performed using Mo-K $\alpha$ radiation $(\lambda=0.71073 \AA$ ) on an Enraf-Nonius Kappa-CCD diffractometer at $293 \mathrm{~K}$. The final unit cell parameters were based on all reflections. Data collections were performed using the COLLECT program [33]. Data reduction was carried out using the Denzo-SMN and Scalepack software [34]. The structures were solved by the direct method using SHELXS-97 and refined using the software SHELXL97 [35].

The hydrogen atoms were calculated at idealized positions using the riding model of SHELXL97 [35]. The Gaussian method was used for the absorption corrections [36]. The projection views of the structures were prepared using ORTEP-3 for Windows [37]. Hydrogen atoms were stereochemically positioned and refined with the riding model.

\subsection{Photophysical characterization}

The UV-vis spectra were acquired using a Beckman DU640 spectrophotometer and the fluorescence spectra were obtained with a Fluorolog-3 spectrofluorometer - Horiba/Jobin-Yvon Inc. The concentrations were monitored spectrophotometrically and all photophysical measurements were performed at room temperature. The flluorescence quantum yield $\left(\Phi_{f}\right)$ was obtained by comparing it with an emission standard of a known compound, as described in reference [22], which was meso-tetrakis(4-N-methylpyridiniumyl) porphyrin (TMPyP) in an aqueous solution at $\mathrm{pH} 6.8$ $\left(\Phi_{f 0}=0.05\right)$ [38]. The $\Phi_{f}$ values were calculated according to Eq. (1).

$\phi_{f}=\phi_{f 0} \frac{F_{f}}{F_{f 0}} \frac{A_{0}}{A} \frac{n^{2}}{n_{0}^{2}}$

where $\Phi_{f}$ and $\Phi_{f o}$ are the quantum yields of the investigated compound and reference, respectively. $A$ and $A_{0}$ are the absorbance values at the excitation wavelength of the compound and reference solutions and $F_{f}$ and $F_{f o}$ are the integrated fluorescence intensities of the compound and reference samples. The sample and the standard were both excited at the same relevant wavelength. $n$ 's are the refractive indexes of the solvents containing the compound $(n)$ and the reference $\left(n_{0}\right)$.

The triplet quantum yields and transient absorptions were obtained through transient absorption experiments. Briefly, samples were excited by a Q-switched, pulsed Nd:YAG laser (Quantel U.S.A. (BigSky) Brilliant B; 5-6 ns full width at halfmaximum (fwhm), $1 \mathrm{~Hz}, \sim 10 \mathrm{~mm}$ in diameter) tuned to $532 \mathrm{~nm}$ by using the appropriate second harmonic generator. A $150 \mathrm{~W}$ xenon arc lamp served as a probe beam and was aligned orthogonally to the laser excitation light. Detection was achieved using a monochromator (Spex 1702/04) optically coupled to a photomultiplier tube (R928, Hamamatsu). More details can be found in [11]. The quantum yields of the formation of the triplet excited state, $\Phi_{i s c}$, were calculated using the partial saturation method, Eq. (2), $[39,40]$.

$\Delta A(\lambda, I)=a\left(1-e^{b I}\right)$ 
where $a=\left[\varepsilon_{T}(\lambda)-\varepsilon_{g}(\lambda)\right] C_{0} L$ and $b=2.3 \Phi_{i s c} \varepsilon_{g}\left(\lambda_{\text {exc }}\right)$. The parameters $\varepsilon_{T}$ and $\varepsilon_{g}$ are the triplet excited state and the ground state extinction coefficients $\left(\mathrm{M}^{-1} \mathrm{~cm}^{-1}\right)$ at the wavelength of analysis while $\varepsilon_{g}\left(\lambda_{\text {exc }}\right)$ is the ground state extinction coefficient at the excitation wavelength $(532 \mathrm{~nm}), C_{O}$ is the sample concentration $\left(\mathrm{mol} \mathrm{L}^{-1}\right), L$ is the optical path of the sample $(\mathrm{cm})$ and $I$ is the intensity of excitation (einstein $\mathrm{cm}^{-2}$ ). The absorbance changes, $\Delta A(\lambda, I)$, were acquired at $420 \mathrm{~nm}$ and $470 \mathrm{~nm}$ for different laser intensities from transient absorption experiments. The probed wavelengths correspond to the ground state bleaching of the singlet and the triplet excited states, respectively.

\subsection{NO photorelease detection}

Chemiluminescent NO detection was used to confirm the release of free NO during the photolysis of (4) and (5) porphyrins in dimethylsulfoxide solutions (DMSO, HPLC grade Sigma-Aldrich). Measurements were carried out in a GE Sievers NOA 280i apparatus, as described in the literature [41]. A xenon lamp XBO $75 \mathrm{~W} / 2$ OFR - OSRAM irradiation induced NO photorelease of porphyrin solutions $(3.0 \mathrm{~mL})$. The irradiance at $320-850 \mathrm{~nm}$ was measured by Spectra-Physics $407 \mathrm{~A}$ radiometer at $0^{\circ}$ of incidence angle and the value used was $870 \pm 70 \mathrm{~mW} \mathrm{~cm}^{-2}$. Optical absorption spectra, before and after irradiation, were monitored by a spectrophotometer. All experiments were performed in a dark room at a temperature of $295.0 \pm 1.0 \mathrm{~K}$.

NO release during porphyrin photolysis was measured at $t=1,000 \mathrm{~s}$ for each sample. The yield reaction of NO release was calculated by Eq. (3), where $\mathrm{M}_{\mathrm{NO}}$ and $\mathrm{M}_{\mathrm{PPh}}$ are the masses of the formed NO and consumed porphyrin, respectively.

$\Phi_{N O}^{P P h}=\frac{M_{N O}}{M_{P P h}}$

\subsection{Photochemical reaction}

The displacement of NO from complex (5) was carried out by irradiation, at $395 \mathrm{~nm}$, of a solution containing $\left\{\mathrm{TPyP}\left[\mathrm{Ru}(\mathrm{NO})\left(5,5^{\prime}-\right.\right.\right.$ Mebipy $\left.)]_{4}\right\}\left(\mathrm{PF}_{6}\right)_{12}(0.02 \mathrm{~g} / 2 \mathrm{~mL}$ of DMSO$)$ and $\left[\mathrm{RuCl}_{3}(\mathrm{dppb})\left(\mathrm{H}_{2} \mathrm{O}\right)\right]$ $\left(0.015 \mathrm{~g} / 2 \mathrm{~mL} \mathrm{CH}_{2} \mathrm{Cl}_{2}\right)$, which was used as a trap to capture the NO released from the porphyrin. The same experiment was performed in the absence of light. The photoreaction experiment was followed by the ${ }^{31} \mathrm{P}\left\{{ }^{1} \mathrm{H}\right\}$ NMR technique.

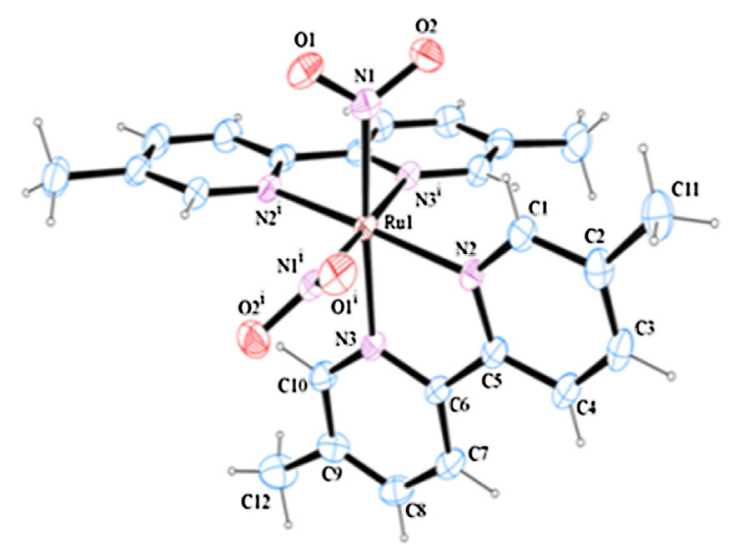

(2)
2.8. Determination of quantum yields for reactive oxygen species (RNOS)

Quantum yields for reactive oxygen species $\left(\Phi_{\Delta}\right)$ were determined using the relative method of a chemical quencher of RNOS 1,3-diphenylisobenzofuran (DPBF) with zinc phthalocyanine as a reference [11,42]. The DPBF was used as an efficient quencher for oxygen singlet [11] and the radical ion as the anion radical superoxide [42].

Porphyrin solutions containing the quencher were prepared in the dark and irradiated in the Q-band region using a $661 \mathrm{~nm}$ laser. The absorbance value of solution was adjusted to $\sim 0.2$ at the irradiation wavelength. The disappearance of DPBF was monitored using a UV-vis spectrophotometer by absorption decays of DPBF at $417 \mathrm{~nm}$. The quantum yields of $\operatorname{ROS}\left(\Phi_{\Delta}\right)$ were determined using:

$\Phi_{\Delta}=\Phi_{\Delta}^{0} \frac{R I_{a b s}^{0}}{R^{0} I_{a b s}}$

where $R$ and $R^{0}$ are the rates of consumption of the DPBF in the presence of the compound under investigation and the reference, respectively. $I_{a b s}$ and $I_{a b s}^{0}$ are the rates of light absorption by the sensitizer under investigation and the reference, respectively. $\Phi \Delta^{0}$ is the quantum yield of the reference for ROS formation. In DMSO, the $\Phi \Delta^{0}$ value for zinc phthalocyanine is 0.67 [11].

\section{Results and discussion}

Complexes (1-5) were obtained in good yields utilizing mild conditions. Elemental analysis and molar conductivity suggest the structures and purity of the complexes. The ${ }^{1} \mathrm{H}$ NMR data for complexes (1) to (5) are summarized to support the information (see Figs. S1-S4 and Table S1). All compounds exhibited wellresolved characteristic ${ }^{1} \mathrm{H}$ NMR peaks. Aromatic hydrogens of 5,5Mebipy and pyrrolic and pyridyl protons of TPyP were found in the range of 7.0-10.0 ppm, giving an integrated signal corresponding to 78 hydrogens and singlets relative to methyl groups, ranging from 2.0 to $2.9 \mathrm{ppm}$, making a total of 48 hydrogens that are consistent with the expected structures for complexes (4) and (5). Singlets observed for the methyl group were confirmed by the COSY ${ }^{1} \mathrm{H}$ NMR experiment. A singlet at $-2.9 \mathrm{ppm}(2 \mathrm{H})$ was assigned to the inner ring protons from the TPyP. The presence of the counter-ion $\mathrm{PF}_{6}{ }^{-}$with a chemical shift at $\delta-144 \mathrm{ppm}$ was confirmed by ${ }^{31} \mathrm{P}\left\{{ }^{1} \mathrm{H}\right\}$ NMR spectra.

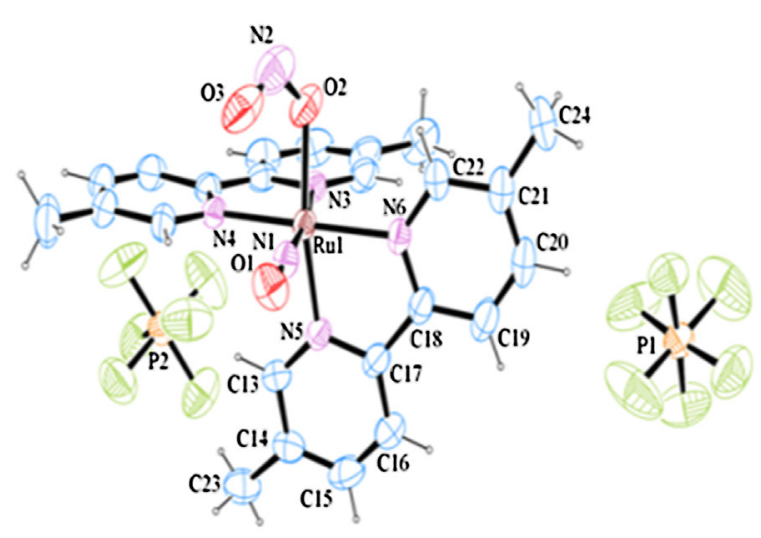

(3)

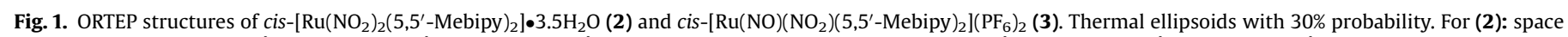
group, $C 2 / c ; a=11.2860(9) \AA, b=17.3225(11) \AA, c=15.3621(12) \AA, \beta=111.104(5)^{\circ}$. For $(3): P 2_{1 / n}, a=9.0970(2) \AA, b=30.4250(6) \AA, c=11.5830(3) \AA, \beta=98.5850(10)^{\circ}$. 
The main IR bands for complexes (1) to (5) are summarized in Figs. S5-S9. IR measurements show that nitrosyl complexes (3) and (5) presented strong bands ranging from 1940 to $1945 \mathrm{~cm}^{-1}$, which are attributed to the $\nu \mathrm{NO}^{+}$stretching [43]. Complexes (2) and (4) presented a $\mathrm{NO}_{2}$ - group coordinated to the metal center by the oxygen, agreeing with a nitro complex with $v_{\text {as }}$ and $v_{\mathrm{s}}$ at $820 \mathrm{~cm}^{-1}$ and $824 \mathrm{~cm}^{-1}$, respectively. At approximately $1331 / 1290 \mathrm{~cm}^{-1}$ and $1328 / 1281 \mathrm{~cm}^{-1}$, stretching of $\nu_{\text {as }} \mathrm{NO}_{2}{ }^{-}$and $v_{\mathrm{s}} \mathrm{NO}_{2}{ }^{-}$for complexes (2) and (4) was also observed, which is consistent with nitro complexes [44]. On the other hand, complex (3) presented a band at $1945 \mathrm{~cm}^{-1}$ assigned to $v \mathrm{NO}^{+}$stretching and $v_{\text {as }}$ and $v_{\mathrm{s}}$, from $\mathrm{NO}_{2}{ }^{-}$ were observed at $1453 \mathrm{~cm}^{-1}$ and $1061 \mathrm{~cm}^{-1}$, respectively. These results are consistent with nitrite complexes and in both cases, the coordination mode was confirmed by crystallographic data (Table S2).

In the IR spectra of complex (5), $v_{\mathrm{s}}$ and $v_{\mathrm{as}}(\mathrm{C}-\mathrm{H})$ aromatic stretching was observed in the region of $3500 \mathrm{~cm}^{-1}$. Both bands, $\mathrm{C}=\mathrm{N}$ and $\mathrm{C}=\mathrm{C}$, of the pyridine rings and $\mathrm{CH}_{3}$ of $5,5^{\prime}$-group were observed ranging from 1630 to $1400 \mathrm{~cm}^{-1}$ [45]. At $827 \mathrm{~cm}^{-1}$ and $547 \mathrm{~cm}^{-1}$, an intense band from $v_{\text {as }}$ and $v_{\mathrm{s}}(\mathrm{P}-\mathrm{F})$ was observed and attributed to the counter-ion. The low intensity band at $547 \mathrm{~cm}^{-1}$ was assigned to the $\nu \mathrm{Ru}-\mathrm{N}$ stretching [45].

The electrochemical behavior for the compounds was evaluated by cyclic voltammetry and differential pulse voltammetry experiments (Fig. S10). Complex (1) showed a reversible process attributed to the oxidation of $\mathrm{Ru}^{\mathrm{II}} / \mathrm{Ru}^{\mathrm{III}}$ where ipa/ipc $=1.0$ and $E_{1 / 2}$ of $291 \mathrm{mV}$, reinforced by differential pulse voltammetry. Complexes (2), (4) and (5) have the presence of a Ru-NO+ fragment in common. Thus, the electrochemistry of these compounds is based on the nitrosyl group $\left(1 \mathrm{~A}: \mathrm{NO}^{+} \rightarrow \mathrm{NO}^{0}, 1 \mathrm{~B}: \mathrm{NO}^{0} \rightarrow \mathrm{NO}^{-}, 2 \mathrm{~A}\right.$ : $\mathrm{NO}^{-} \rightarrow \mathrm{NO}^{0}$ and $2 \mathrm{~B}: \mathrm{NO}^{0} \rightarrow \mathrm{NO}^{+}$).

Cyclic voltammogram of complex (3) showed a quasi-reversible process (ipa/ipc $=1.11)$ with Epa and Epc values of 821 and $736 \mathrm{mV}$, respectively. This can be attributed to the redox pair of $\mathrm{Ru}^{\mathrm{II}}-\mathrm{NO}_{2}$ to $\mathrm{Ru}^{\mathrm{III}}-\mathrm{NO}_{2}$ [46]. After oxidation the $\left[\mathrm{Ru}^{\mathrm{III}}-\left(\mathrm{NO}_{2}\right)_{2}\left(5,5^{\prime}-\mathrm{Mebipy}\right) 2\right]^{2+}$ species has a limited stability due to the easy intermolecular disproportionation reaction, which is responsible for the formation of the nitrite and nitrosyl complex, as previously reported for the cis-[Ru(NO 2$\left.)_{2}(\text { bipy })_{2}\right]$ compound [46].

\section{1. $X$ ray diffraction}

Single crystals suitable for X-ray diffraction of complexes (2) and (3) were obtained by slow evaporation of methanol/hexane (4:1) solutions at room temperature. Complexes (2) and (3) crystallized into a monoclinic crystalline system and space group $\mathrm{C} 2 / \mathrm{c}$ and $\mathrm{P} 2 / \mathrm{n}$, respectively (Table S2). In the structure of complex (2) (Fig. 1), $\mathrm{H}_{2} \mathrm{O}$ molecules were omitted for the sake of clarity.

Complexes (2) and (3) exhibit the expected octahedral coordination geometries: the two bidentate 5,5'-Mebiby ligands are situated in position cis to each other and the ligand $\mathrm{NO}_{2}{ }^{-}$in complex (2) is in the cis position to $\mathrm{NO}_{2}{ }^{-}$, and in complex (3), $\mathrm{NO}_{2}$ is also situated cis to NO. The nitrite ion is coordinated by the oxygen atom (O2) with O2-N2-O3 bond angle of 116.7 (8) A. The bond distances O1-N1, N2-O2, and N2-O3 (1.130 (5) 1.244 (8) and 1.147 (8) $\AA$ ) are within the range reported for other nitrite complexes [44] (Table S3).

The Ru-N3 distance in complex (3), which is trans to Ru-N1(NO) is 2.087 (4) $\AA$, while Ru-N5 (5,5'-Mebipy) trans to ONO is practically the same, 2.090 (4) $\AA$. The bond distances Ru-N1(NO) and Ru-O2 (ONO) are 1.758 (4) and 2.067 (4), respectively. The nitrosyl structure is practically in a linear coordination mode and the structural parameters, typical for Ru-NO complexes [43,44], are consistent with the IR data.

Complex (2) presents a symmetrical structure with space group $\mathrm{C} 2 / \mathrm{c}$ and consequently the distances of the atoms are identical, as can be observed in $\mathrm{Ru}(1)-\mathrm{N}(1)$ and $\mathrm{Ru}(1)-\mathrm{N}(1)^{\mathrm{i}} 2.033(2) \AA$ and $\mathrm{Ru}$ $(1)-\mathrm{N}(2)$ and $\mathrm{Ru}(1)-\mathrm{N}(2)^{\mathrm{i}} 2.078(2) \AA$. . The bond distances, O1-N1 and N2-O2, 1.231 (3) and 1.268 (3) Å respectively, and 01-N1$\mathrm{O} 2$ angle $117.2(2)$, are in agreement with the literature on nitro complexes $[45,46]$.

\subsection{UV-vis absorbance and fluorescence emission}

The electronic spectra for complex (1-3) are summarized in the supplementary material (Table S4). The electronic (black curve) and fluorescence emission (gray curve) spectra for TPyP $\left\{\left[\mathrm{Ru}\left(\mathrm{NO}_{2}\right)\right.\right.$ $\left(5,5^{\prime}-\right.$ Mebipy $\left.\left.)\right]_{4}\right\}\left(\mathrm{PF}_{6}\right)_{4}$ (4) and $\operatorname{TPyP}\left\{\left[\mathrm{Ru}(\mathrm{NO})\left(5,5^{\prime}-\text { Mebipy }\right)\right]_{4}\right\}$ $\left(\mathrm{PF}_{6}\right)_{12}(5)$, in DMSO are presented in Fig. 2a and b, respectively. The band around $300 \mathrm{~nm}$ can be attributed to the $\pi \AA \pi^{*}$ intraligand transition of unsaturation in 5,5'-Mebipy ligands, while the band at $420 \mathrm{~nm}$ can be assigned as the B-band of porphyrins and the bands ranging from 515 to $647 \mathrm{~nm}$ are the Qbands. The molar absorption coefficients were obtained in different concentrations from 1 to $100 \mu \mathrm{M}$ for the maximum of the main peaks, in Table 1.

The fluorescence spectra of these samples show the wellknown dual emission of free base porphyrins. The fluorescence quantum yield was obtained and the results show that for complex (4) it is 0.002 , while for complex (5) it is 0.003 .

\subsection{Triplet state formation}

Nanosecond transient absorption experiments for a great variety of porphyrins have been extensively reported in the
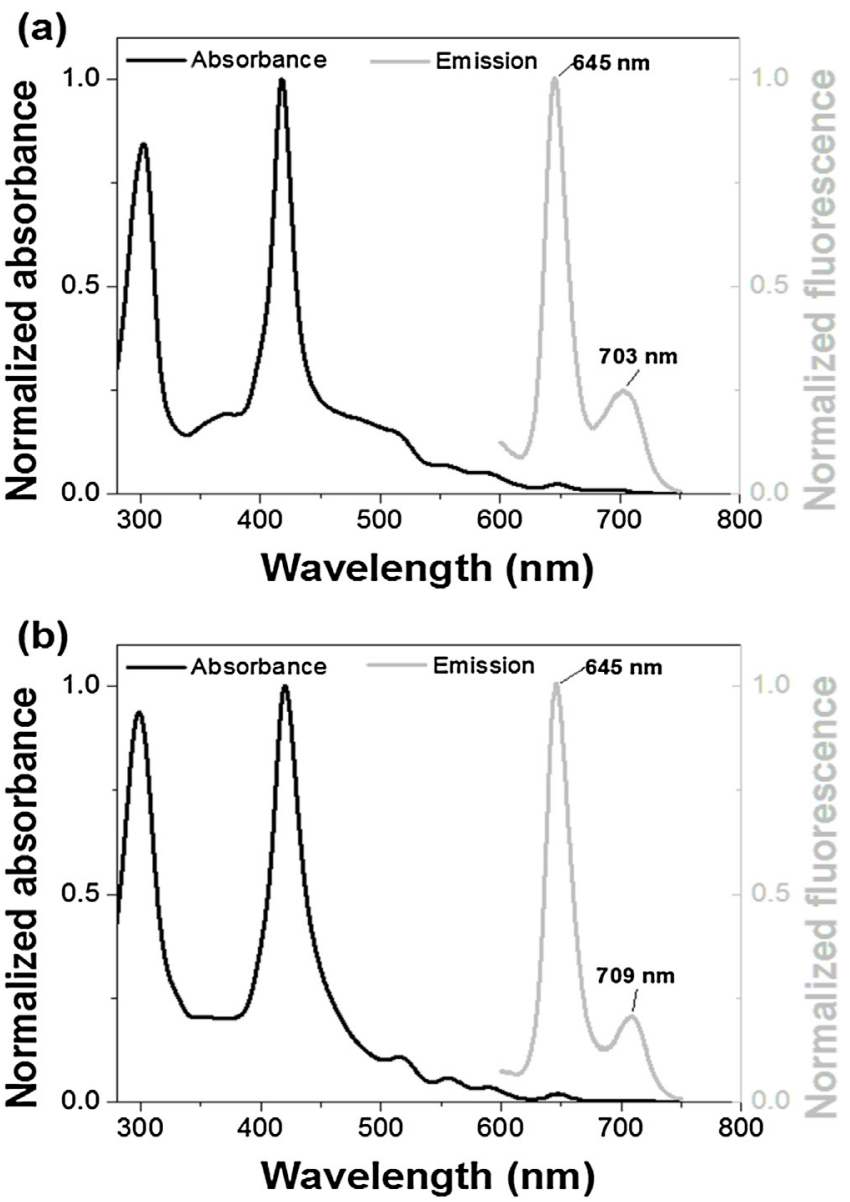

Fig. 2. Absorption spectrum in the UV/Vis region (black curve) and fluorescence emission spectrum (gray curve): (a) complex (4) and (b) complex (5) in DMSO. 
Table 1

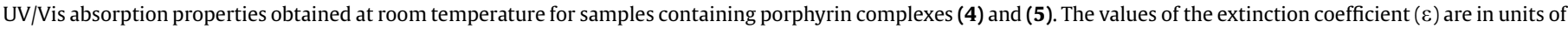
$10^{5} \mathrm{M}^{-1} \mathrm{~cm}^{-1}, \pm$ standard deviation. The wavelengths, in $\mathrm{nm}$, for the center of the observed bands are presented between parentheses.

\begin{tabular}{|c|c|c|c|c|c|c|}
\hline Complex & Intraligand Band & B-Band & $\mathrm{Q}_{\mathrm{y}}(1,0)$ & $\mathrm{Q}_{\mathrm{y}}(0,0)$ & $\mathrm{Q}_{\mathrm{x}}(1,0)$ & $\mathrm{Q}_{\mathrm{x}}(0,0)$ \\
\hline (4) & $2.38 \pm 0.05(300)$ & $2.96 \pm 0.09$ (419) & $\begin{array}{l}0.47 \pm 0.02 \\
(514)\end{array}$ & $0.23 \pm 0.01(545)$ & $0.16 \pm 0.04(590)$ & $0.07 \pm 0.01(647)$ \\
\hline (5) & $2.15 \pm 0.03(300)$ & $2.17 \pm 0.05(420)$ & $0.21 \pm 0.05$ & $0.11 \pm 0.01$ & $0.31 \pm 0.01(590)$ & $0.03 \pm 0.01(647)$ \\
\hline
\end{tabular}

literature regarding the formation and dynamics of triplet states [47-52]. The transient absorption spectrum of a free base tetrapyridyl porphyrin shows characteristic ground state bleaching between $400 \mathrm{~nm}$ and $430 \mathrm{~nm}$ and a growth from $430 \mathrm{~nm}$ to $500 \mathrm{~nm}$ [52]. In transient absorption, a positive signal represents an increase in absorption, and generally for porphyrins, this is assigned to the triplet excited state absorption, $\mathrm{T}_{1} \rightarrow \mathrm{T}_{\mathrm{n}}$.

Transient absorption of porphyrin complexes (4) and (5) depicted very distinct triplet excited state behavior although they differ slightly in their molecular structure (see Fig. 3). Both compounds exhibit tri-exponential kinetics for the triplet excited state relaxation, as shown in Table 2 . The origin of each time constant will not be further discussed since it is not the main aim of the current research. The most relevant aspect here is to show that both compounds have a long lived triplet excited state and their calculated triplet quantum yield is 0.09 and 0.27 for complexes (4) and (5), respectively.

\subsection{NO photorelease from nitrosyl ruthenium porphyrins complexes}

The nitrosyl ruthenium porphyrin complexes, when dissolved in DMSO are stable in the dark, but upon irradiation with visible light, the solution of (4) and (5) release nitric oxide (NO) as demonstrated by spectral modifications (Fig. 4) and NO• chemiluminescent signal (Fig. 5).

The decrease in the absorption of the band at $420 \mathrm{~nm}$ (Fig. 4) can be attributed to the consumption of the initial complex, while the band centered at $300 \mathrm{~nm}$ is associated to the intraligand $\pi \rightarrow \pi^{*}$ transitions in 5,5'-Mebipy ligands [48]. The porphyrin transition bands in the region $330-550 \mathrm{~nm}$ in the UV-vis spectra are sufficiently intense to mask the metal ligand charge transfer

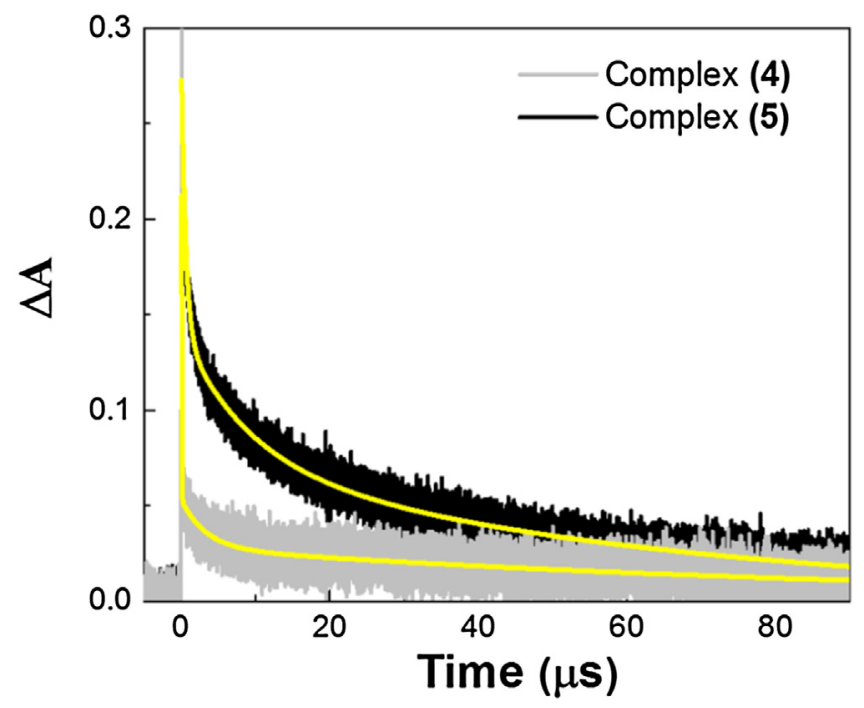

Fig. 3. Absorption changes monitored at $460 \mathrm{~nm}$ after pulsed light excitation $\left(\lambda_{\mathrm{exc}}=532 \mathrm{~nm}\right.$ and $1 \mathrm{~mJ} /$ pulse $)$ of complex (4), gray curve and complex (5), black curve, in DMSO solution. The yellow line corresponds to a tri-exponential function. (For interpretation of the references to colour in this figure legend, the reader is referred to the web version of this article.).
Table 2

Depopulation time constants and formation quantum yield of triplet state for $\{$ TPyP $\left.\left[\mathrm{Ru}\left(\mathrm{NO}_{2}\right)\left(5,5^{\prime}-\mathrm{Mebipy}\right)\right]_{4}\right\}\left(\mathrm{PF}_{6}\right)_{4}$ (4) and (b) $\left\{\mathrm{TPyP}\left[\mathrm{Ru}(\mathrm{NO})\left(5,5^{\prime}-\mathrm{Mebipy}\right)\right]_{4}\right\}\left(\mathrm{PF}_{6}\right)_{12}$ (5) in DMSO.

\begin{tabular}{lllll}
\hline Compound & $\tau_{1}{ }^{\mathrm{a}}$ & $\tau_{2}{ }^{\mathrm{a}}$ & $\tau_{3}{ }^{\mathrm{a}}$ & $\Phi_{\mathrm{T}}$ \\
\hline $\mathbf{( 4 )}$ & $2.8 \times 10^{-8}(94 \%)$ & $3.2 \times 10^{-6}(3 \%)$ & $9.5 \times 10^{-5}(3 \%)$ & 0.09 \\
$\mathbf{( 5 )}$ & $5.8 \times 10^{-7}(50 \%)$ & $8.9 \times 10^{-6}(24 \%)$ & $6.4 \times 10^{-5}(26 \%)$ & 0.27 \\
\hline
\end{tabular}

a The numbers between parenthesis represent the contribution of the time constant to the overall kinetics.

(MLCT) involving $\mathrm{d}_{\pi}\left(\mathrm{Ru}^{\mathrm{II}}\right) \rightarrow \pi^{*}\left(5,5^{\prime}-\right.$ Mebipy) and $\mathrm{d} \pi\left(\mathrm{Ru}^{\mathrm{II}}\right) \rightarrow \pi^{*}$ $\left(\mathrm{NO}^{+}\right)$in the case of complex (5) or $\mathrm{d}_{\pi}\left(\mathrm{Ru}^{\mathrm{III}}\right) \rightarrow \pi^{*}\left(5,5^{\prime}-\right.$ Mebipy $)$ and $\mathrm{d} \pi\left(\mathrm{Ru}^{\mathrm{III}}\right) \rightarrow \pi^{*}\left(\mathrm{ONO}^{-}\right.$) for complex (4) (Figs. S11-S13).

Thus, the spectral changes are associated with nitrosyl ligand reduction $\left(\mathrm{NO}^{+} \rightarrow \mathrm{NO}^{00}\right)$ in the case of complex (5) and \{TPyP $\left.\left[\mathrm{Ru}^{\mathrm{III}} \text { (solvent)(5,5'-Mebipy) }\right]_{4}\right\}\left(\mathrm{PF}_{6}\right)_{12}$ formation, as suggested by controlled reduction potential (electrolysis), performed in $\mathrm{CH}_{3} \mathrm{CN}$,
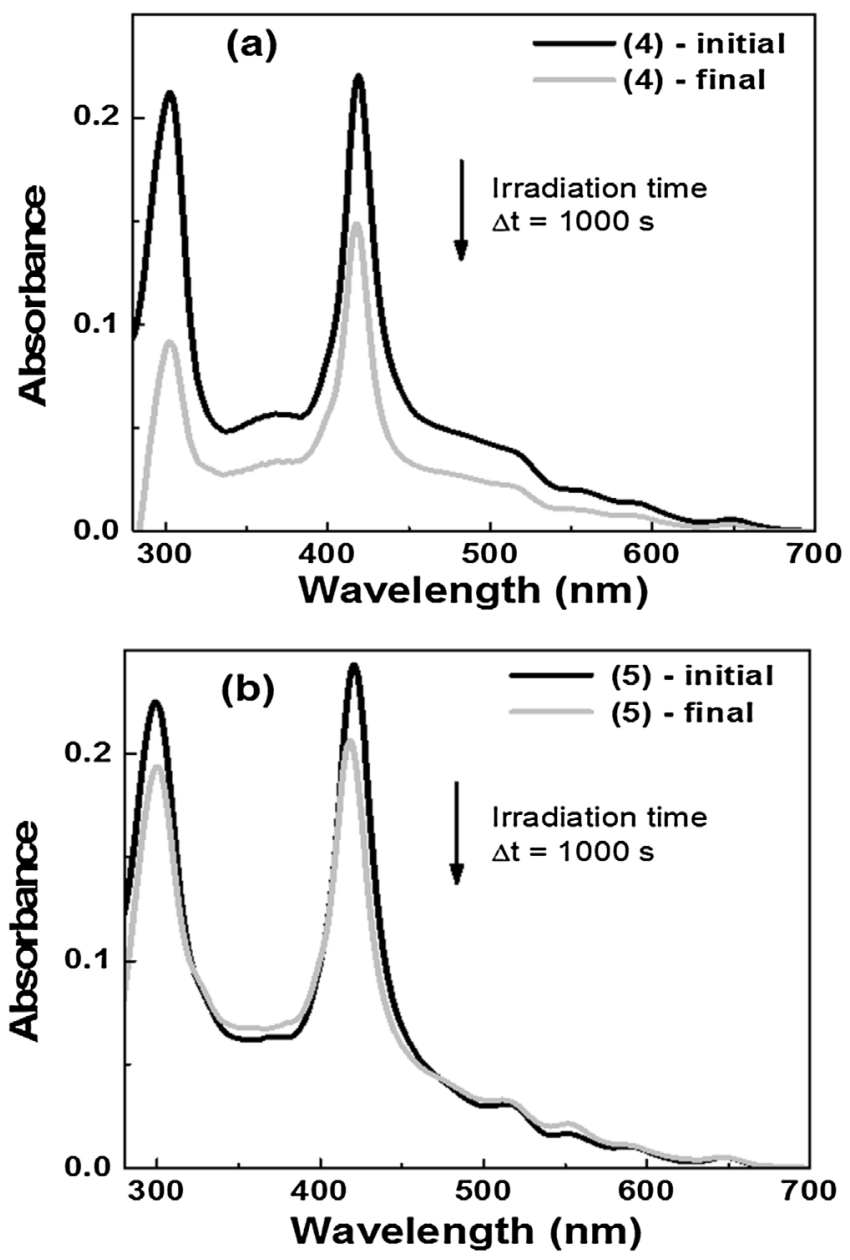

Fig. 4. Absorption spectra modifications for porphyrin solutions upon irradiation with visible light during $\Delta \mathrm{t}=1000 \mathrm{~s}$. (a) $\left\{\mathrm{TPyP}\left[\mathrm{Ru}\left(\mathrm{NO}_{2}\right)\left(5,5^{\prime}-\mathrm{Mebipy}\right)\right]_{4}\right\}\left(\mathrm{PF}_{6}\right)_{4}$ (4) and (b) $\left\{\mathrm{TPyP}\left[\mathrm{Ru}(\mathrm{NO})\left(5,5^{\prime}-\mathrm{Mebipy}\right)\right]_{4}\right\}\left(\mathrm{PF}_{6}\right)_{12}$ (5). 


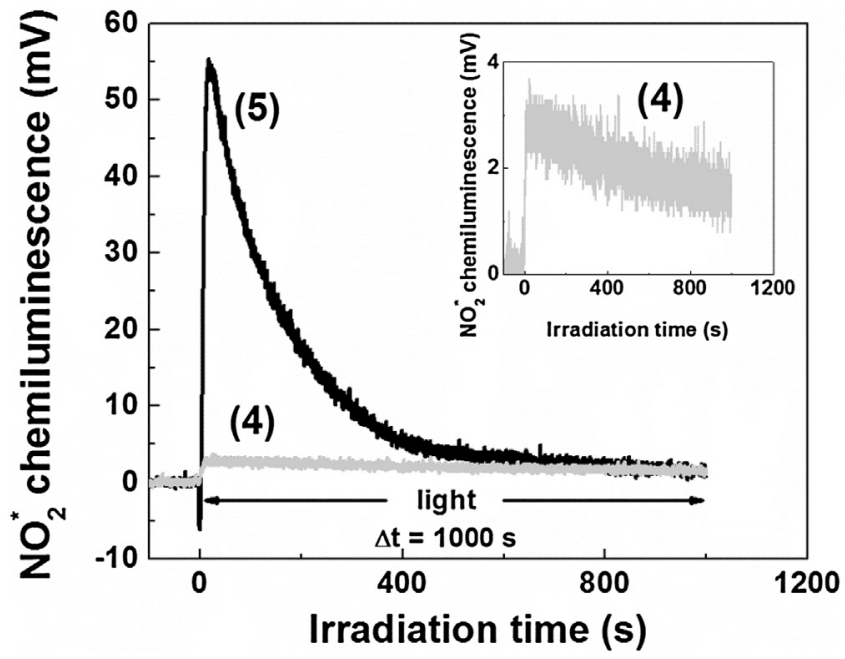

Fig. 5. Chemiluminescent signal from photolysis of (4) and (5) compounds irradiated with visible light during $\Delta t=1000 \mathrm{~s}$. The inset shows the rescaled (4) curve.

0.1 M PTBA (Fig. S10e). The changes in the complex (4) spectrum were associated with nitrite ligand oxidation $\left(\mathrm{ONO}^{-} \rightarrow \mathrm{NO}^{0}\right)$ and subsequent formation of metal - oxo species. In this case, there was no metal-solvent coordination since the ruthenium of complex (4) has an octahedral structure (TPyP $\left.\left[\mathrm{Ru}^{\mathrm{IV}}=\mathrm{O}^{-}\right]\right)$ (Fig. S10d). NO photolabilization from the coordinated ruthenium complex has been demonstrated by a direct labilization of the $\mathrm{Ru}$ - NO bond, in our case complex (5), and by homolytic $\mathrm{O}-\mathrm{NO}$ cleavage resulting in a metal - oxo species, in this study as complex (4) [53-55].

The detection of NO was directly registered by the chemiluminescence emitted from the $\mathrm{NO}_{2}$ excited state $\left(\mathrm{NO}_{2}{ }^{*}\right)$. The amount of NO released ( $\mathrm{M}_{\mathrm{NO}}$, in moles) from the porphyrin complexes during photolysis was calculated taking the ratio of the area under the decay curve (Fig. 5 ) by the proportionality constant $\mathrm{B}=7.9 \pm 0.2$ $\times 10^{12} \mathrm{mV} \mathrm{s} \mathrm{mol}^{-1}$. Constant B was obtained from the calibration curve as previously reported [41] (Fig. S14). Additionally, the amount of porphyrin consumed ( $\mathrm{M}_{\mathrm{PPh}}$, in moles) is directly determined from the optical absorption spectra at the Soret band, acquired immediately before and after photolysis (see Fig. 5), according to Eq. (5).

$M_{P P h}=\frac{\left(A_{\text {initial }}-A_{\text {final }}\right) \cdot \text { volume }}{\varepsilon_{\text {Soret-band }}}$

Compared to the initial amount of porphyrins in the reaction flask, the amount of NO released represents a reaction yield of $0.53 \pm 0.03 \mathrm{~mol}$ of NO per mol of (5) and $0.05 \pm 0.01 \mathrm{~mol}$ of NO per mol of (4). These results are summarized in Table 3.

The NO quantum yield is highly dependent on the structure of nitrosyl porphyrin ruthenium complexes, TPyP $\left[\mathrm{Ru}^{\mathrm{II}}-\mathrm{N} \equiv \mathrm{O}\right]$ or TPyP $\left[\mathrm{Ru}^{\mathrm{III}}-\mathrm{O}-\mathrm{N}=\mathrm{O}\right]$. The lower reaction photorelease yield of free NO for complex (4) could be explained in terms of the recombination reaction between $\mathrm{NO}^{+}$and $\mathrm{TPyP}\left[\mathrm{Ru}^{\mathrm{IV}}=\mathrm{O}^{-}\right]$, as

Table 3

Amounts of NO released $\left(\mathrm{M}_{\mathrm{NO}}\right)$ and porphyrin consumed $\left(\mathrm{M}_{\mathrm{PPh}}\right)$ during the photolysis of $\left\{\mathrm{TPyP}\left[\mathrm{Ru}\left(\mathrm{NO}_{2}\right)\left(5,5^{\prime}-\mathrm{Mebipy}\right)\right]_{4}\right\}\left(\mathrm{PF}_{6}\right)_{4}$ (4) and $\left\{\mathrm{TPyP}\left[\mathrm{Ru}(\mathrm{NO})\left(5,5^{\prime}-\right.\right.\right.$ Mebipy $\left.)]_{4}\right\}\left(\mathrm{PF}_{6}\right)_{12}(\mathbf{5})$ porphyrins. The reaction yield of NO release $\left(\Phi_{\mathrm{NO}}^{P P h}\right)$ was determined for an irradiation time of $\Delta t=1,000 \mathrm{~s}$.

\begin{tabular}{llll}
\hline Complexes & $M_{P P h}\left(\times 10^{-12}\right.$ moles $)$ & $M_{N O}\left(\times 10^{-12}\right.$ moles $)$ & $\Phi_{N O}^{P P h}$ \\
\hline $\mathbf{( 4 )}$ & $730 \pm 10$ & $40 \pm 10$ & $0.05 \pm 0.03$ \\
$(5)$ & $570 \pm 10$ & $300 \pm 10$ & $0.53 \pm 0.03$ \\
\hline
\end{tabular}

suggested in Ref. [53]. It is supported by a predominantly (>50\%) short triplet lifetime and lower triplet quantum yield, $\tau_{1}=2.8 \times 10^{-8} \mathrm{~s}$ and $\Phi \mathrm{T}=0.09$, respectively (Table 2 ). These data indicate that NO release is one of the processes involved in the dissipation of the triplet state energy, since the intersystem crossing process to the complex (4) ground state is lower.

NO photorelease from complex (5) was monitored by the photoreactivity of nitrosyl $\left(\mathrm{NO}^{\circ}\right)$ with $\left[\mathrm{Ru}^{\mathrm{III}} \mathrm{Cl}_{3}(\mathrm{dppb})\left(\mathrm{H}_{2} \mathrm{O}\right)\right]$, which in turn was reduced to $\left[\mathrm{Ru}^{\mathrm{II}}(\mathrm{NO}) \mathrm{Cl}_{3}(\mathrm{dppb})\right]$ and is confirmed by ${ }^{31} \mathrm{P}$ $\left\{{ }^{1} \mathrm{H}\right\}$ NMR data. The $\left[\mathrm{Ru}^{\mathrm{II}}(\mathrm{NO}) \mathrm{Cl}_{3}(\mathrm{dppb})\right]{ }^{31} \mathrm{P}\left\{{ }^{1} \mathrm{H}\right\}$ NMR spectrum shows a chemical shift at $14.6 \mathrm{ppm}$ and $11.1 \mathrm{ppm}$, whose phosphorus atoms of dppb are trans-dppb-NO and trans-dppb$\mathrm{Cl}$, respectively (Fig. S15) [56]. On the other hand, in the absence of light, no chemical shift and consequently no reduction of $\mathrm{Ru}^{\mathrm{III}}$ complex was detected, indicating an absence of $\mathrm{NO}^{00}$ photoreleasing.

Additionally, another mechanism should also be involved in the NO production from similar nitrosyl ruthenium complexes. It has been reported that under air atmosphere and upon ultraviolet irradiation, photoinduced electron transfer could be present in the photoredox transformations of a nitrosyl phthalocyanine ruthenium complex, resulting in superoxide anion $\left(\mathrm{O}_{2}^{--}\right)$formation [57].

This hypothesis is corroborated by the fact that the estimated Qband energy for $\{\mathrm{TPyP}[\mathrm{Ru}(\mathrm{NO})\}$ is $2.17 \mathrm{eV}$, and the ground state $\left\{\mathrm{TPyP}[\mathrm{Ru}(\mathrm{NO})\}^{+} /\left\{\mathrm{TPyP}[\mathrm{Ru}(\mathrm{NO})\}^{0}\right.\right.$ reduction potential is $+1.17 \mathrm{~V}$. Thus, the estimated $\Delta E_{0,0}$ gives the $\left\{\mathrm{TPyP}[\mathrm{Ru}(\mathrm{NO})\}^{+} /\{\mathrm{TPyP}[\mathrm{Ru}\right.$ (NO) $\}^{*}$ potential as $-1.00 \mathrm{eV}$ for the singlet state, which implies that $\left\{\mathrm{TPyP}[\mathrm{Ru}(\mathrm{NO})\}^{*}\right.$ can easily reduce molecular oxygen to superoxide anion, since molecular oxygen has a one-electron reduction potential of $-0.33 \mathrm{eV}[57,58]$. This mechanism could also be present for complex (4), $\left\{\mathrm{TPyP}\left[\mathrm{Ru}\left(\mathrm{NO}_{2}\right)\left(5,5^{\prime}-\mathrm{Mebipy}\right)\right]_{4}\right\}\left(\mathrm{PF}_{6}\right)_{4}$, $\Delta E_{0,0}=-1.55 \mathrm{eV}$. Moreover, it is well known that superoxide can react quickly with nitric oxide producing peroxynitrite $\left(\mathrm{ONOO}^{-}\right)$ and could also be in the photochemical reaction [59].

\subsection{Determination of quantum yields for reactive nitrogen and oxygen species (RNOS)}

RNOS quantum yield $\left(\Phi_{\boldsymbol{\Delta}}\right)$ values were calculated by Eq. (4) according to Fig. S16. The $\Phi_{\Delta}$ values obtained for (4) and (5) were 0.07 and 0.78 , respectively. The generation of the RNOS depends on the formation of the triplet state from the PS. Thus, the RNOS quantum yield is limited by a triplet quantum yield $\left(\Phi_{\boldsymbol{\Delta}} \leq \Phi_{T}\right)$. However, the $\Phi_{\Delta}$ for compound (5) was 0.78 and $\Phi_{T}$ was 0.27 , indicating that a second mechanism is involved in ROS formation. As the $\Phi_{\boldsymbol{\Delta}}$ for complex (5) (0.78) is consistent with the sum of quantum yields NO release $(0.53)$ and triplet state $(0.27)$, we believe that another mechanism involved is the photorelease of the NO radical.

Therefore, both photodynamic processes participate in the formation of reactive oxygen species and reactive nitrogen species, contributing to the increase in photodynamic efficiency of the studied compounds. This result is in agreement with other photosensitizer-NO compounds [60]. Thus, Schemes 2 and 3 summarize the photochemical pathway for the photolysis of the investigated nitrosyl porphyrin ruthenium complexes.

\section{Conclusions}

In this paper, we report the synthesis and characterization of three new nitro/nitrosyl Ru-based complexes, which were used as precursors to obtain two new porphyrin ruthenium species containing nitric oxide (NO) or nitrogen dioxide $\left(\mathrm{NO}_{2}\right)$, able to generate NO. The NO photorelease, triplet state and reactive oxygen species formation by these ruthenium porphyrins were 


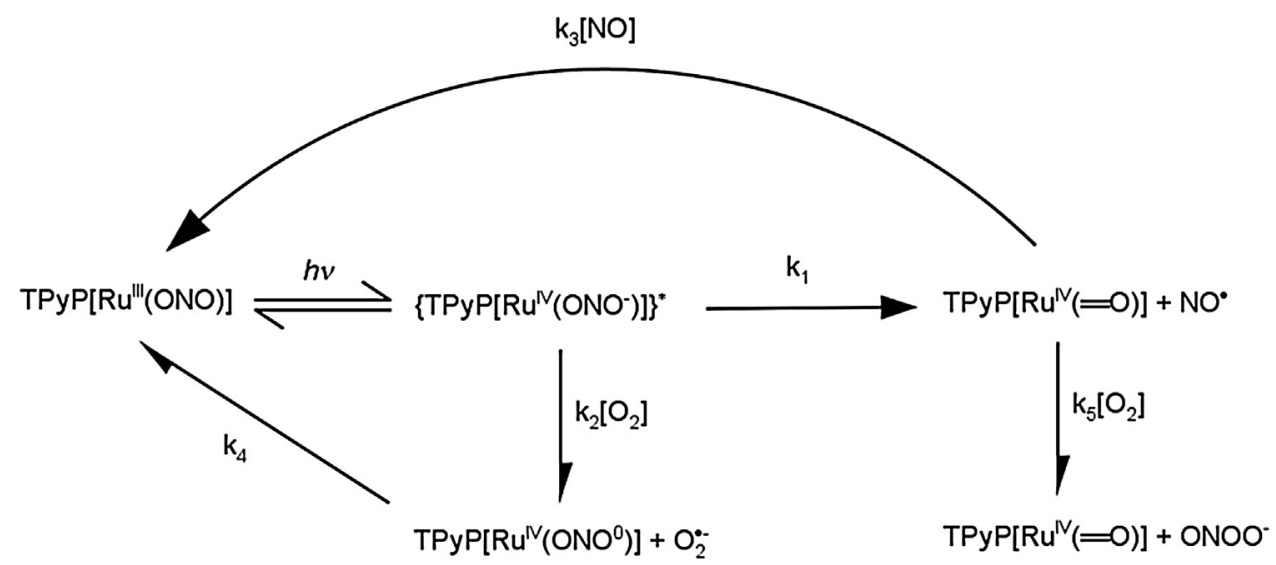

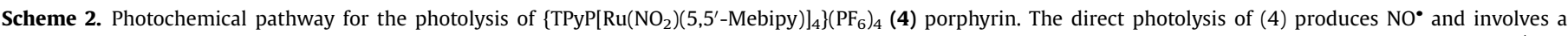

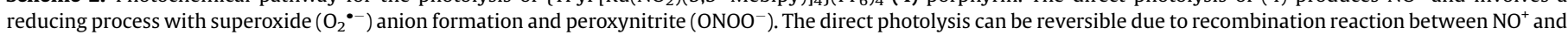
$\mathrm{TPyP}\left[\mathrm{Ru}^{\mathrm{IV}}=\mathrm{O}^{-}\right]$.

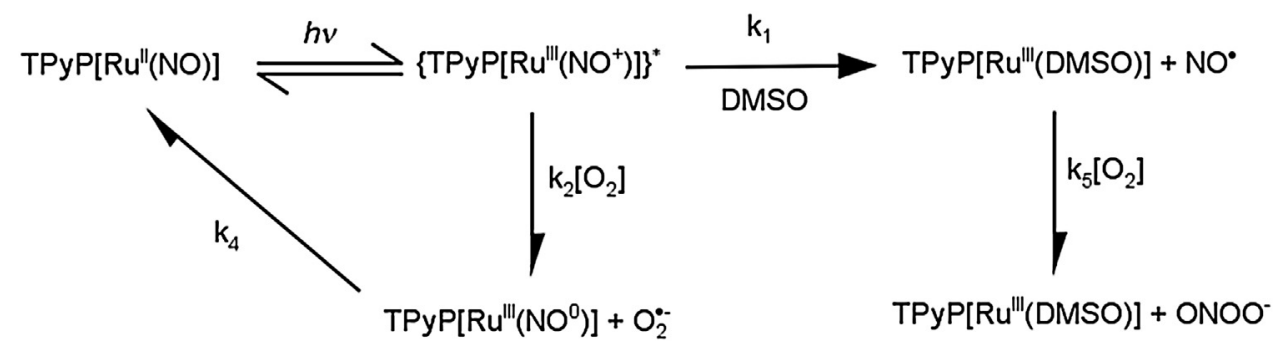

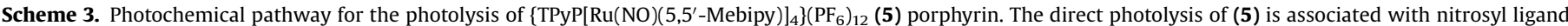

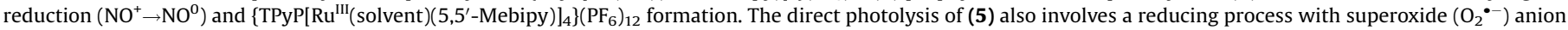
formation and peroxynitrite $\left(\mathrm{ONOO}^{-}\right)$.

evaluated and followed by photochemical and photophysical characterization. The results suggest that the $\left\{\mathrm{TPyP}\left[\mathrm{Ru}\left(\mathrm{NO}_{2}\right)\left(5,5^{\prime}-\right.\right.\right.$ Mebipy $\left.)]_{4}\right\}\left(\mathrm{PF}_{6}\right)_{4}$ (complex 4) and the $\left\{\mathrm{TPyP}\left[\mathrm{Ru}(\mathrm{NO})\left(5,5^{\prime}-\right.\right.\right.$ Mebipy) $\left.]_{4}\right\}\left(\mathrm{PF}_{6}\right)_{12}$ (complex 5) porphyrins are able to produce reactive nitrogen species and reactive oxygen species on the same platform and the highest production was observed for complex (5). These results could improve the photodynamic action of these compounds, which could be potential drugs for cancer treatment and other diseases.

\section{Acknowledgements}

The authors would like to acknowledge the Fundação de Amparo à Pesquisa do Estado de Goiás (FAPEG), the Fundação de Amparo à Pesquisa do Estado de Minas Gerais (FAPEMIG), the Fundação de Amparo à Pesquisa do Estado de São Paulo (FAPESP), the Coordenação de Aperfeiçoamento de Pessoal de Nivel Superior (CAPES) and the Conselho Nacional de Desenvolvimento Científico e Tecnológico (CNPq) for the financial support for this research. The authors are very grateful to Prof. Gerald J. Meyer from the University of North Carolina for the use of the transient absorption experimental setup. We would also like to thank the Grupo de Física dos Materiais (IF/UFG) for allowing us access to their spectrofluorometer (Fluorolog FL3-221; Horiba Jobin Yvon Inc.).

\section{Appendix A. Supplementary data}

Supplementary data associated with this article can be found, in the online version, at http://dx.doi.org/10.1016/j. jphotochem.2017.01.028.

\section{References}

[1] K. Plaetzer, B. Krammer, J. Berlanda, F. Berr, T. Kiesslich, Photophysics and photochemistry of photodynamic therapy: fundamental aspects, Lasers Med. Sci. 24 (2009) 259-268.

[2] A.E. O'Connor, W.M. Gallagher, A.T. Byrne, Porphyrin and nonporphyrin photosensitizers in oncology: preclinical and clinical advances in photodynamic therapy, Photochem. Photobiol. 85 (2009) 1053-1074.

[3] J.M. Dabrowski, L.G. Arnaut, Photodynamic therapy (PDT) of cancer: from local to systemic treatment, Photochem. Photobiol. Sci. 14 (2015) 1765-1780.

[4] M. Kim, H.Y. Jung, H.J. Park, Topical PDT in the treatment of benign skin diseases: principles and new applications, Int. J. Mol. Sci. 16 (2015) 2325923278 .

[5] D.A. Caminos, M.B. Spesia, E.N. Durantini, Photodynamic inactivation of Escherichia coli by novel meso-substituted porphyrins by 4-(3-N,N,Ntrimethylammoniumpropoxy)phenyl and 4-(trifluoromethyl)phenyl groups, Photochem, Photobiol. Sci. 5 (2006) 56-65.

[6] M.R. Detty, S.L. Gibson, S.J. Wagner, Current clinical and preclinical photosensitizers for use in photodynamic therapy, J. Med. Chem. 47 (2004) 3897-3915.

[7] P. Braham, C. Herron, C. Street, R. Darveau, Antimicrobial photodynamic therapy may promote periodontal healing through multiple mechanisms, J. Periodontol. 80 (2009) 1790-1798.

[8] L.M. Almeida, F.F. Zanoelo, K.P. Castro, I.E. Borissevitch, C.M.A. Soares, P.J. Gonçalves, Cell survival and altered gene expression following photodynamic inactivation of paracoccidioides brasiliensis, Photochem. Photobiol. 88 (2012) 992-1000.

[9] G.B. Kharkwal, S.K. Sharma, Y.Y. Huang, T. Dai, M.R. Hamblin, Photodynamic therapy for infections: clinical applications, Lasers Surg. Med. 43 (2011) 755767.

[10] X. Zhou, D. Liu, T. Wang, X. Hu, J. Guo, K.C. Weerasinghe, L. Wang, W. Li, Synthesis and photophysical studies of triazine-linked porphyrin-perylene bisimide dyad with long-lived perylene triplet state, J. Photochem. Photobiol. A 274 (2014) 57-63.

[11] L. Alonso, R.N. Sampaio, T.F.M. Souza, R.C. Silva, N.M. Barbosa Neto, A.O. Ribeiro, A. Alonso, P.J. Gonçalves, Photodynamic evaluation of tetracarboxyphthalocyanines in model systems, J. Photochem. Photobiol. B 161 (2016) 100107. 
[12] M.P. Romero, N.R.S. Gobo, K.T. de Oliveira, Y. Iamamoto, O.A. Serra, S.R.W. Louro, Photophysical properties and photodynamic activity of a novel menthol-zinc phthalocyanine conjugate incorporated in micelles, J. Photochem. Photobiol. A 253 (2013) 22-29.

[13] B. Pucelik, I. Gürol, V. Ahsen, F. Dumoulin, J.M. Dabrowski, Fluorination of phthalocyanine substituents: improved photoproperties and enhanced photodynamic efficacy after optimal micellar formulations, Eur. J. Med. Chem. 124 (2016) 284-298.

[14] K. Ogawa, Y. Kobuke, Recent advances in two-photon photodynamic therapy, Anticancer Agents Med. Chem. 8 (2008) 269-279.

[15] L. De Boni, D.S. Correa, D.L. Silva, P.J. Gonçalves, S.C. Zílio, G.G. Parra, I.E. Borissevitch, S. Canuto, C.R. Mendonça, Experimental and theoretical study of two-photon absorption in nitrofuran derivatives: promising compounds for photochemotherapy, J. Chem. Phys. 134 (2011) 014509.

[16] G.C. Bolfarini, M.P. Siqueira-Moura, G.J.F. Demets, P.C. Morais, A.C. Tedesco, In vitro evaluation of combined hyperthermia and photodynamic effects using magnetoliposomes loaded with cucurbit[7]uril zinc phthalocyanine complex on melanoma, J. Photochem. Photobiol. B 115 (2012) 1-4.

[17] T. Gianferrara, I. Bratsos, E. Iengo, B. Milani, A. Ostric, C. Spagnul, E. Zangrando, Enzo Alessio, Synthetic strategies towards ruthenium?porphyrin conjugates for anticancer activity, Dalton Trans. 48 (2009) 10742-10756.

[18] T. Gianferrara, A. Bergamo, I. Bratsos, B. Milani, C. Spagnul, G. Sava, E. Alessio Ruthenium-porphyrin conjugates with cytotoxic and phototoxic antitumor activity, J. Med. Chem. 53 (2010) 4678-4690.

[19] S. Rani-Beeram, K. Meyer, A. McCrate, Y. Hong, M. Nielsen, S. Swavey, A fluorinated ruthenium porphyrin as a potential photodynamic therapy agent: synthesis, characterization, DNA binding, and melanoma cell studies, Inorg. Chem. 47 (2008) 11278-11283.

[20] M. Pernot, T. Bastogne, N.P.E. Barry, B. Therrien, G. Koellensperger, S. Hann, V. Reshetov, M. Barberi-Heyob, Systems biology approach for in vivo photodynamic therapy optimization of ruthenium-porphyrin compounds, J. Photochem. Photobiol. B 117 (2012) 80-89.

[21] A. Frei, R. Rubbiani, S. Tubafard, O. Blacque, P. Anstaett, A. Felgentragger, T. Maisch, L. Spiccia, G. Gasser, Synthesis, characterization, and biological evaluation of new $\mathrm{Ru}(\mathrm{II})$ polypyridyl photosensitizers for photodynamic therapy, J. Med. Chem. 57 (2014) 7280-7292.

[22] R.N. Sampaio, W.R. Gomes, D.M.S. Araujo, A.E.H. Machado, R.A. Silva, A. Marletta, I.E. Borissevitch, A.S. Ito, L.R. Dinelli, A.A. Batista, S.C. Zílio, P.J. Gonçalves, N.M. Barbosa Neto, Investigation of ground- and excited-State photophysical properties of 5,10,15,20-Tetra(4-pyridyl)-21H,23H-porphyrin with ruthenium outlying complexes, J. Phys. Chem. A 116 (2012) 18-26.

[23] L. Huang, Y. Xuan, Y. Koide, T. Zhiyentayev, M. Tanaka, M.R. Hamblin, Type I and Type II mechanisms of antimicrobial photodynamic therapy: an in vitro study on Gram-negative and Gram-positive bacteria, Lasers Surg. Med. 44 (2012) 490-499.

[24] D.E.J.G.J. Dolmans, D. Fukumura, R.K. Jain, Photodynamic therapy for cancer, Nat. Rev. Cancer 3 (2003) 380-387.

[25] M.G. Sauaia, R.G. de Lima, A.C. Tedesco, R.S. da Silva, Nitric Oxide Procuction by visble ligth irradiation of aqueous solution of Nitrosyl Rethenium Complexes, Inorg. Chem. 44 (2005) 9946-9951.

[26] S.A. Cicillini, A.C.L. Prazias, A.C. Tedesco, O.A. Serra, R.S. da Silva, Nitric oxide and singlet oxygen photo-generation by light irradiation in the phototherapeutic window of a nitrosyl ruthenium conjugated with a phthalocyanine rare earth complex, Polyhedron 28 (2009) 2766-2770.

[27] W. Xu, L.Z. Liu, M. Loizidou, M. Ahmed, I.G. Charles, The role of nitric oxide in cancer, Cell Res. 12 (2002) 311-320.

[28] S. Mocellin, V. Bronte, D. Nitti, Nitric oxide, a double edged sword in cancer biology: searching for therapeutic opportunities, Med. Res. Rev. 27 (2007) 317352.

[29] J.C.G. Rotta, C.N. Lunardi, A.C. Tedesco, Nitric oxide release from the Snitrosothiol zinc phthalocyanine complex by flash photolysis, Braz. J. Med. Biol. Res. 36 (2003) 587-594.

[30] T.A. Heinrich, A.C. Tedesco, J.M. Fukuto, R.S. da Silva, Production of reactive oxygen and nitrogen species by light irradiation of a nitrosyl phthalocyanine ruthenium complex as a strategy for cancer treatment, Dalton Trans. 43 (2014) 4021-4025.

[31] J.B. Godwin, T.J. Meyer, Preparation of ruthenium nitrosyl complexes containing 2,2'-bipyridine and 1,10-phenanthroline, Inorg. Chem. 10 (1971) 471-474.

[32] J.B. Godwin, T.J. Meyer, Nitrosyl-nitrite interconversion in ruthenium complexes, Inorg.Chem 10 (1971) 2150-2153.

[33] Enraf-Nonius, Collect, Nonius BV, Delft, The Netherlands, 1997-2000.

[34] Z. Otwinowski, W. Minor, Processing of X-ray diffraction data collected in oscillation mode, Methods Enzymol. 276 (1997) 307-326.

[35] G.M. Sheldrick, ShelXS-97 Program for Crystal Structure Resolution, University of Göttingen, Göttingen, Germany, 1997.

[36] R.H. Blessing, An empirical correction for absorption anisotropy, Acta Crystallogr. A 51 (1995) 33-38.

[37] L.J. Farrugia, ORTEP-3 for windows - a version of ORTEP-III with a graphical user interface (GUI), J. Appl. Crystallogr. 30 (1997) 565-565.
[38] P.J. Gonçalves, P.L. Franzen, D.S. Correa, L.M. Almeida, M. Takara, A.S. Ito, S.C. Zílio, I.E. Borissevitch, Effects of environment on the photophysical characteristics of mesotetrakis methylpyridiniumyl porphyrin (TMPyP), Spectrochim. Acta A 79 (2011) 1532-1539.

[39] C.A. Strassert, G.M. Bilmes, J. Awruch, L.E. Dicelio, Comparative photophysical investigation of oxygen and sulfur as covalent linkers on octaalkylamino substituted zinc(II) phthalocyanines, Photochem. Photobiol. Sci. 7 (2008) 738747.

[40] C. Ian, G.L. Hug, Triplet-triplet absorption spectra of organic molecules in condensed phases, J. Phys. Chem. Ref. Data 15 (1986) 1-250.

[41] N.A. Daghastanli, I.A. Degterev, G.B. Olivera, A.B. Seabra, M.G. de Oliveira, I.E Borissevitch, Formation of cytotoxic intermediates in the course of photodecomposition of a nitroheterocyclic antiseptic quinifuryl, J. Photochem. Photobiol. A 184 (2006) 98-104.

[42] T. Ohyashiki, M. Nunomura, T. Katoh, Detection of superoxide anion radical in phospholipid liposomal membrane by fluorescence quenching method using 1,3-diphenylisobenzofuran, Biochim Biophys. Acta 1421 (1999) 131-139.

[43] M.G. Sauaia, F.S. Oliveira, A.C. Tedesco, R.S. da Silva, Control of NO release by light irradiation from nitrosyl-ruthenium complexes containing polypyridyl ligands, Inorg. Chim. Acta 355 (2003) 191-196.

[44] N. Nagao, D. Ooyama, K. Oomura, Y. Miura, S. Howell, M. Mukaida, Ligand nature of coordinated $\mathrm{NO} 2$ - in the oxidation reaction of $\mathrm{Ru}(\mathrm{II})$ complexes, [Ru $(\mathrm{NO} 2)(\mathrm{OH} 2)(\mathrm{py}) 4-2 \mathrm{n}(\mathrm{bpy}) \mathrm{n}]+(\mathrm{n}=0,1,2)$, and their related complexes, Inorg. Chim. Acta 225 (1994) 111-121.

[45] S.L. Queiroz, A.A. Batista, G. Oliva, M.T.P. Gambardella, R.H.A. Santos, K.S MacFarlane, S.J. Retting, B.R. James, The reactivity of five-coordinate Ru(II) (1,4bis(diphenylphosphino)butane) complexes with the N-donor ligands: ammonia, pyridine, 4-substituted pyridines, 2,2'-bipyridine, bis(o-pyridyl) amine, 1,10-phenanthroline, 4,7-diphenylphenanthroline and ethylenediamine, Inorg. Chim. Acta 267 (1998) 209-221.

[46] A.Y. Ershov, P.V. Kucheryavyi, A. B.Nikol'skii, Chemistry of ruthenium polypyridine complexes: IX. Nitro-Nitrosyl equilibrium in cis-[Ru(2, 2'-bpy) 2(L)NO2]+ complexes, Russ. J. Gen. Chem. 74 (2004) 651-654.

[47] M. Ghirotti, C. Chiorboli, M.T. Indelli, F. Scandola, M. Casanova, E. Iengo, E. Alessio, Energy transfer pathways in pyridylporphyrin Re(I) adducts, Inorg. Chim. Act. 360 (2007) 1121-1130.

[48] M.G. Sauaia, R.G. de Lima, A.C. Tedesco, R.S. da Silva, Photoinduced NO release by visible light irradiation from pyrazi-bridged nitrosyl ruthenium complexes, J. Am. Chem. Soc. 125 (2003) 14718-14719.

[49] T.A. Heinrich, A.C. Tedesco, J.M. Fukuto, R.S. da Silva, Photoinduced NO release by visible light irradiation from pyrazi-bridged nitrosyl ruthenium complexes, Dalton Trans. 43 (2014) 4021-4025.

[50] R.V. Maximiano, E. Piovesan, S.C. Zílio, A.E.H. Machado, R. de Paula, J.A.S Cavaleiro, I.E. Borissevitch, A.S. Ito, P.J. Gonçalves, N.M. Barbosa Neto, Excitedstate absorption investigation of a cationic porphyrin derivative, J. Photochem. Photobiol. A 214 (2010) 115-120.

[51] N.M. Barbosa Neto, D.S. Correa, L. De Boni, G.G. Parra, L. Misoguti, C.R. Mendonça, I.E. Borissevitch, S.C. Zílio, P.J. Gonçalves, Excited states absorption spectra of porphyrins-Solvent effects, Chem. Phys. Lett. 587 (2013) 118-123.

[52] R.N. Sampaio, M.M. Silva, A.A. Batista, N.M. Barbosa Neto, Investigation of the photophysical and eletrochemical properties of a free base tetrapyridyl porphyrin with meso carbon linked ruthenium(II) groups, J. Photochem. Photobiol. 315 (2016) 98-106.

[53] I.M. Lorković, K.M. Miranda, B. Lee, S. Bernhard, J.R. Schoonover, P.C. Ford, Flash photolysis studies of the Ruthenium(II) porphyrins $\mathrm{Ru}(\mathrm{P})(\mathrm{NO})(\mathrm{ONO})$. multiple pathways involving reactions of intermediates with nitric oxide, J. Am. Chem. Soc. 120 (1998) 11674-11683.

[54] K.S. Suslick, R.A. Watson, Photochemical reduction of nitrate and nitrite by manganese and iron porphyrins, Inorg. Chem. 30 (1991) 912-919.as

[55] M. Yamaji, Y. Hama, Y. Miyazaki, M. Hoshino, Photochemical formation of oxochromium(IV) tetraphenylporphyrin from nitritochromium(III) tetraphenylporphyrin in benzene, Inorg. Chem. 31 (1992) 932-934.

[56] R.S. Corrêa, J.P. Barolli, M.I.F. Barbosa, J. Ellena, A.A. Batista, The effect of guest molecules on the conformation and molecular assembly of the fac-[RuCl3(NO) (dppb)] complex, J. Mol. Struct. 1048 (2013) 11-17.

[57] Z.N. da Rocha, R.G. de Lima, F.G. Doro, E. Tfouni, R.S. da Silva, Photochemical production of nitric oxide from a nitrosyl phthalocyanine ruthenium complex by irradiation with light in the phototherapeutic window, Inorg. Chem. Commun. 11 (2008) 737-740.

[58] Z.A. Carneiro, J.C.B. De Moraes, F.P. Rodrigues, R.G. De Lima, C. Curti, Z.N. Da Rocha, M. Paulo, L.M. Bendhack, A.C. Tedesco, A.L.B. Formiga, R.S. da Silva, Photocytotoxic activity of a nitrosyl phthalocyanine ruthenium complex - A system capable of producing nitric oxide and singlet oxygen, J. Inorg. Biochem. 105 (2011) 1035-1043.

[59] G.L. Squadrito, W.A. Pryor, Oxidative chemistry of nitric oxide: the roles of superoxide, peroxynitrite, and carbon dioxide, Free Radic. Biol. Med. 25 (1998) 392-403.

[60] A. Fraix, A.R. Gonçalves, V. Cardile, A.C.E. Graziano, T.A. Theodossiou, K. Yannakopoulou, S. Sortino, A multifunctional bichromophoric nanoaggregate for fluorescence imaging and simultaneous photogeneration of RNOS and ROS Chem. Asian J. 8 (2013) 2634-2641. 